\title{
Enhancer of Filamentation 1
}

National Cancer Institute

\section{Source}

National Cancer Institute. Enhancer of Filamentation 1. NCI Thesaurus. Code C71008.

Enhancer of filamentation 1 (834 aa, $\sim 93 \mathrm{kDa}$ ) is encoded by the human NEDD9 gene.

This protein plays a role in the docking of kinases and adaptor molecules that are involved in integrin-mediated signaling pathways. 